\title{
Coulisses
}

Revue de théâtre

10 | Printemps 1994

Varia

\section{Il était une fois...}

\section{Q OpenEdition}

1 Journals

Édition électronique

URL : http://journals.openedition.org/coulisses/3147

DOI : $10.4000 /$ coulisses.3147

ISSN : 2546-9460

\section{Éditeur}

Presses universitaires de Franche-Comté

\section{Édition imprimée}

Date de publication : 1 juin 1994

Pagination : 81

ISSN : 1150-594X

\section{Référence électronique}

« Il était une fois... », Coulisses [En ligne], 10 | Printemps 1994, mis en ligne le 15 mars 2019, consulté le

21 octobre 2019. URL : http://journals.openedition.org/coulisses/3147 ; DOI : 10.4000/coulisses.3147

Ce document a été généré automatiquement le 21 octobre 2019

Coulisses 


\section{Il était une fois...}

PREMIERE : Mercredi 8 juin, 21h30 à L'Amphithéâtre de plein air de l'UFR-STAPS. 31 rue de l'Epitaphe. Bus $n^{\circ} 8$, arrêt Providence.

Création collective : groupe de Besançon.

Mise en scène : Joseph MELCORE.

Depuis sa création, le Théâtre Universitaire de Franche-Comté, met en scène de grands groupes, entre quarante et cinquante étudiants, de toutes disciplines sans formation préalable. Pour permettre à chacun d'exprimer sa part de créativité, «la création collective » ou "le montage de textes » a été préféré à la réécriture de pièces de répertoire. Ce choix permettait également de s'associer à des commémorations diverses et de valoriser les sites universitaires: le bicentenaire de la révolution a donné naissance à TRAJECTOIRES dans la cour, dite du cloître, de la Faculté des Lettres ; LA MIRIFIQUE HISTOIRE DE BLANC-BEC pour le trentième anniversaire de l'I.U.F.C. a fait découvrir un tout autre aspect du hall de la propédeutique Faculté des Sciences; $\mathbf{L E}$ JARDIN DES DELICES a conféré un aspect magique à la cour Chifflet de la Faculté des Lettres; les habitués du terrain de sports du campus de La Bouloie ne s'attendaient certes pas à ce qu'il devienne le théâtre d'ELECTRE 90.

IL ETAIT UNE FOIS met en scène une quarantaine d'étudiants dans l'amphi de plein air de l'UFR-STAPS. La pièce est créée dans le cadre de BVOJ.

Le spectacle est placé sous le patronage de Pierre Jakez HELIAs qui demandant à un conteur Breton, «pourquoi contez-vous? », entendit cette réponse : «si je conte c'est pour réagir contre tout ce qui nous brime. »

Il établit ainsi le rapport entre le conte et le théâtre. Tous deux fondés sur la présence et l'oralité : quelle que soit la tradition dont ils sont issus, ils se présentent comme l'intercesseur entre le rêve et la réalité. Ils établissent une connivence avec le public, pour s'émouvoir et rire ensemble. Ils rassemblent la mémoire collective et l'expérience individuelle. "Il était une fois " : la formule magique va permettre aux spectateurs de découvrir un bien-être de vivre ensemble l'émotion délicieuse de la peur et de la magie. 